\title{
Characterization of Northern Spring Flax as a Winter Crop for Southeast Texas
}

\author{
Abdul Razack Mohammed ${ }^{1}$, Leon Carl Holgate ${ }^{1} \&$ Lee Tarpley $^{1}$ \\ ${ }^{1}$ Texas A\&M AgriLife Research Center, Beaumont, Texas, USA \\ Correspondence: Abdul Razack Mohammed, Texas A\&M AgriLife Research Center, 1509 Aggie Drive, \\ Beaumont, Texas 77713, USA. Tel: 1-409-752-2741 ext. 2319. E-mail: abdulrazack@email.tamu.edu
}

\author{
Received: April 27, $2017 \quad$ Accepted: June 1, $2017 \quad$ Online Published: July 15, 2017 \\ doi:10.5539/jas.v9n8p1 URL: https://doi.org/10.5539/jas.v9n8p1
}

This research was partially funded by the Chevron Technology Ventures.

\begin{abstract}
Increasing interest in biodiesel production led to flax being evaluated as a potential biodiesel crop throughout the USA. The objectives of this study were 1) to determine if northern spring flax varieties can be grown as a winter crop in the southeast Texas environment, 2) characterize the varieties under the southeast Texas environment and 3 ) to determine if northern spring flax varieties can be grown on a laser-leveled field with $17.8 \mathrm{~cm}$ row spacing rather than raised beds. In this study, five northern spring flax varieties, Nekoma, Omega, Pembina, Prairie Thunder and York were grown as a winter crop in Beaumont, Texas on a laser-leveled field. The flax varieties were characterized with respect to morphology, phenology and physiology. In the present study, Omega and Pembina were taller compared to the other varieties. Nekoma had more branches, whereas Omega had more immature capsules per plant, compared to other varieties. Leaf photosynthetic rate was higher in Omega and Prairie Thunder, compared to other varieties. At harvest, Omega and York had more mature capsules, and greater capsule weight and shoot weight per plant, compared to other varieties. Due to delayed machine harvest, there was decrease in flax seed yield due to capsule dehiscence and shattering. Omega had more capsule dehiscence and shattering, compared to other varieties. Seeds of Nekoma and Pembina had more oil content and Omega and Pembina had more protein content. All the above flax varieties have potential to be used as an oilseed crop for biodiesel production in southeast Texas.
\end{abstract}

Keywords: flax, Nekoma, Omega, Pembina, Prairie Thunder, York

\section{Introduction}

Flax (Linum usitatissimum L.) is an oilseed and fiber crop (Jhala \& Hall, 2010) that belongs to the family Linaceae and has its origin in Europe and Asia (Berglund \& Zollinger, 2002). It is the third largest natural fiber crop and one of the five major oil crops in the world (Pali \& Mehta, 2014). Flax is a well established crop in many countries due to its positive health effects and numerous industrial uses. According to the Food and Agricultural Organization (FAO, 2010), the six major countries that produce flax are Canada, China, India, Russia, Kazakhstan and Ethiopia. In the USA, North Dakota, South Dakota, and Minnesota produce the majority of the flax seed and North Dakota is the leading state for flax production (Berglund \& Zollinger, 2002). In Texas, flax was grown in the coastal area in the 1950's, but due to severe drought over years, Texas flax acreage declined and has remained negligible since the 1980's (National Agricultural Statistics Service-United States Department of Agriculture [NASS-USDA], 2011).

Flax seed yield is highly associated with the number of primary branches, pod (capsule) number per plant and number of seeds per capsule (Nie, Shi, \& Zhu, 1995; Kaynak, 1998; Can, Yuce, \& Demir, 2001; Can, Yuce, Aykut, \& Furan, 2003). Many environmental factors affect flax yield and oil quality. Air and soil temperature along with rainfall, day length (photoperiodism) and soil drainage play an important role in flax production (Casa, Russell, Lo Cascio, \& Rossini, 1999; Darapuneni, Morgan, Ibrahim, \& Duncan, 2014a; Darapuneni, Morgan, Ibrahim, \& Duncan, 2014b). Flax is a temperate climate crop (Casa et al., 1999), and its morphology, phenology and yield mainly depends on the temperature during the crop development (Cross, McKay, McHughens, \& Bonham-Smith, 2003). Temperatures below $28{ }^{\circ} \mathrm{F}\left(-2{ }^{\circ} \mathrm{C}\right)$ can cause severe cold injury and can 
potentially affect plant stand (Darapuneni et al., 2014a). Cooler temperature $\left(<16^{\circ} \mathrm{C}\right)$ can delay capsule maturity and reduce the number of seeds per capsule and total seed yield. High temperatures $\left(>20^{\circ} \mathrm{C}\right)$ during reproductive phase reduce seed number per capsule, seed weight, oil yield and quality (Dybing \& Zimmermen, 1965). Under hot and dry conditions, irrigation at flowering and grain filling considerably increases oil yield and quality (Tiwari, Dixit, \& Saran 1988; Dutta, Ram Mohan Rao, \& Singh, 1995). However, irrigation or rainfall during the latter part of the cropping season can also result in a flush of new tillers causing uneven ripening (Diepenbrock \& Iwersen, 1989).

Flax can be been grown under a wide range of soils (medium to heavy textured soils with $\mathrm{pH}$ 6; Hocking, Randall, \& Pinkerton, 1987). Flax grows best on well-drained conditions, hence, it is typically grown on raised beds. Increasing interest in biodiesel led to flax being evaluated as a potential biodiesel crop throughout the U.S. Identifying appropriate varieties for a particular climatic region is essential for crop development and improvement. The objectives of this study were 1) to determine if northern spring flax varieties can be grown as winter crop in the southeast Texas environment, 2) to characterize the varieties under the southeast Texas environment and 3) to determine if northern spring flax varieties can be grown on a laser-leveled field with 17.8 $\mathrm{cm}$ row spacing (similar to that of rice) rather than raised beds.

\section{Material and Methods}

\subsection{Plant Culture and Climatic Conditions}

The field experiments were conducted at the Texas A\&M AgriLife Research Center at Beaumont, Texas, USA $\left(29^{\circ} 57^{\prime} \mathrm{N}\right.$ lat; $94^{\circ} 30^{\prime} \mathrm{W}$ long) during 2010 and 2011 . The soil at this site is an Entic Pelludert (fine, montmorillonitic, and thermic), with a sand, silt, and clay composition of 3.2, 32.4, and 64.4\%, respectively (Samonte et al., 2006). The soil at this site has poor drainage (Natural Resources Conservation Services-United States Department of Agriculture [NRCS-USDA], 2006). Each plot was $10.4 \mathrm{~m}^{2}$ and consisted of 8 rows. In this study, flax spring varieties from Canada and the Northern US were planted as winter crop in Southeast Texas. The five flax varieties: Nekoma, Omega, Pembina, Prairie Thunder and York (Table 1) were grown on a laser-leveled field (0.2\% slope gradient). Planting was done on October 20, 2010. A drill (John Deere, Illinois, USA) was used to plant the seed at a depth of $2.5 \mathrm{~cm}$. The seeding rate was $45 \mathrm{~kg} / \mathrm{ha}$. On October $27,2010,75 \%$ emergence was seen. Nitrogen, phosphorus and potassium were applied at the rate $163 \mathrm{~kg} / \mathrm{ha}, 49 \mathrm{~kg} / \mathrm{ha}$ and 49 $\mathrm{kg} / \mathrm{ha}$, respectively, at 91 days after planting and 126 days after planting. Harvesting was done using an Almaco plot harvester (Almaco, Iowa, USA), 196 days after planting.

Table 1. Flax varieties characterized for Southeast Texas region during 2010-2011

\begin{tabular}{lll}
\hline Varieties & Developer & Release date \\
\hline Nekoma & NDSURF $^{\dagger}$ & 2002 \\
Omega & USDA $^{\ddagger}$ and NDSU & 1989 \\
Pembina & NDSURF & 1999 \\
Prairie Thunder & AAFC & 2006 \\
York & NDSURF & 2002
\end{tabular}

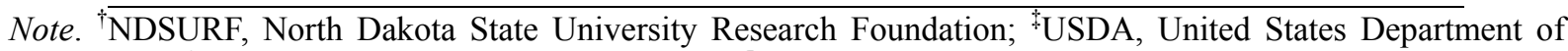
Agriculture; ${ }^{\S} \mathrm{NDSU}$, North Dakota State University; ${ }^{\circledR}$ AAFC, Agriculture and Agri-food Canada.

The weather data at Texas A\&M AgriLife Research Center at Beaumont, Texas, USA ( $29^{\circ} 57^{\prime} \mathrm{N}$ lat; $94^{\circ} 30^{\prime} \mathrm{W}$ long) was obtained from the Beaumont Center database (Yang, Wilson, \& Wang, 2010). During the cropping season, the monthly maximum and minimum air temperatures varied between $15{ }^{\circ} \mathrm{C}$ to $30^{\circ} \mathrm{C}$ and $6{ }^{\circ} \mathrm{C}$ to $19{ }^{\circ} \mathrm{C}$ (Table 2). The maximum and minimum soil temperatures varied between $14{ }^{\circ} \mathrm{C}$ to $30{ }^{\circ} \mathrm{C}$ and $9{ }^{\circ} \mathrm{C}$ to $23{ }^{\circ} \mathrm{C}$ (Table 2). The maximum and minimum relative humidity varied between $91 \%$ to $95 \%$ and $34 \%$ to $55 \%$ (Table 2 ). The monthly rain fall, wind speed and solar radiation varied between $1.2 \mathrm{~mm}$ to $129 \mathrm{~mm}, 135 \mathrm{~km} /$ day to $238 \mathrm{~km} / \mathrm{day}$ and 10 $\mathrm{MJ} / \mathrm{m}^{2} /$ day to $23 \mathrm{MJ} / \mathrm{m}^{2} /$ day, respectively (Table 2). 
Table 2. Average monthly minimum and maximum air and soil temperature, relative humidity, rainfall, wind speed and solar radiation during the cropping season (2010-2011) in southeast Texas (Beaumont, TX)

\begin{tabular}{|c|c|c|c|c|c|c|c|c|}
\hline Month & October & November & December & January & February & March & April & May \\
\hline Air $\mathrm{T}_{\max }^{\dagger}$ & 29 & 22 & 18 & 15 & 18 & 24 & 28 & 30 \\
\hline Air $\mathrm{T}_{\text {min }}{ }^{\ddagger}$ & 14 & 10 & 6 & 4 & 7 & 13 & 17 & 19 \\
\hline Soil $\mathrm{T}_{\max }$ & 27 & 21 & 17 & 14 & 15 & 21 & 27 & 30 \\
\hline Soil $\mathrm{T}_{\min }$ & 21 & 16 & 13 & 9 & 11 & 16 & 21 & 23 \\
\hline $\mathrm{RH}_{\max } \S$ & 91 & 95 & 92 & 91 & 95 & 95 & 91 & 91 \\
\hline $\mathrm{RH}_{\text {min }}{ }^{\text {ॠ }}$ & 34 & 55 & 49 & 53 & 58 & 52 & 46 & 48 \\
\hline $\mathrm{RF}^{\#}$ & 12 & 54 & 88 & 110 & 23 & 129 & 13 & 22 \\
\hline $\mathrm{WS}^{*}$ & 135 & 190 & 215 & 192 & 219 & 205 & 238 & 226 \\
\hline $\mathrm{SR}^{\circ}$ & 19 & 12 & 10 & 10 & 12 & 16 & 20 & 23 \\
\hline
\end{tabular}

Note. ${ }^{\dagger} \mathrm{T}_{\max }$, mean monthly maximum temperature in ${ }^{\circ} \mathrm{C} ;{ }^{\ddagger} \mathrm{T}_{\min }$, mean monthly minimum temperature in ${ }^{\circ} \mathrm{C}$;

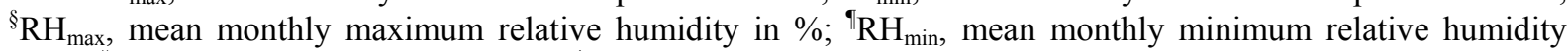
in \%; ${ }^{*} \mathrm{RF}$, rainfall in millimeter $(\mathrm{mm})$; "WS, mean monthly wind speed in kilometers per day ( $\left.\mathrm{km} / \mathrm{day}\right)$; 'SR, mean monthly solar radiation in mega joules per square meter per day $\left(\mathrm{MJ} / \mathrm{m}^{2} /\right.$ day $)$.

\subsection{Morphology, Phenology and Dry Weights}

At harvest, plant height was measured; numbers of branches per plant and mature capsules per plant were counted. Date of flowering was recorded, and immature capsules per plant were counted. Shoot and capsule dry weights per plant were determined at harvest.

\subsection{Mechanical Harvest}

Machine harvest was delayed due to poor weather conditions. Each plot was separately harvested using an Almaco plot harvester (Almaco, Iowa, USA). Harvest was conducted 189 days after emergence (DAE). The harvested seed was dried in a sack drier to a moisture level of $10 \%$ which is the recommended moisture level to safely store flax seed.

\subsection{Leaf Photosynthesis, Seed Oil and Protein Content}

The net photosynthetic rate $\left(\mathrm{P}_{\mathrm{N}}\right)$ of the penultimate leaves was measured using a LI-6400 portable photosynthesis system (LI-COR Inc., Lincoln, Nebraska, USA), 148 DAE. The $\mathrm{P}_{\mathrm{N}}$ was measured between 1000 $\mathrm{h}$ and $1200 \mathrm{~h}$. When measuring $\mathrm{P}_{\mathrm{N}}$, the light intensity, temperature and $\mathrm{CO}_{2}$ concentration in the leaf cuvette were set to $1500 \mu \mathrm{mol} \mathrm{m} \mathrm{s}^{-2}, 25{ }^{\circ} \mathrm{C}$ and $390 \mathrm{ppm}$, respectively. Seed oil content was measured using Nuclear Magnetic Resonance (NMR; Bruker Minispec MQOne Seed Analyzer, Bruker BioSpin Corporation, Billerica, Massachusetts, USA) and seed nitrogen using FP-528 Nitrogen/Protein analyzer (LECO Corporation, St. Joseph, Michigan, USA).

\subsection{Experimental Design and Data Analysis}

The experiment was setup as randomized complete block design (RCBD). There were two blocks (two locations) and five treatments (varieties), with eight replications in each block. The data were analyzed using the PROC GLM procedures in SAS software (SAS statistical analysis package version 9.2, SAS Institute, Inc., Cary, NC) to test the significance difference between blocks and among the varieties for different parameters measured. The means were separated using Tukey's least significant difference (LSD) at an alpha level of 0.05 . If there was no significant difference among the blocks for a parameter, then the values from both the blocks for that parameter were used to obtain the mean and error. The standard errors of the mean were also calculated and presented in the graphs as error bars.

\section{Results}

\subsection{Morphology, Phenology, and Dry Weights}

There was no difference between the blocks for plant height, numbers of branches, immature and mature capsules, capsule weight and shoot dry weight per plant. However, Omega $(56.4 \mathrm{~cm})$ and Pembina $(56.5 \mathrm{~cm})$ were taller compared to the other varieties at harvest. Nekoma, Prairie Thunder and York were $7 \%, 9 \%$ and $12 \%$ shorter compared to Omega (Figure 1A). In this study, Nekoma (2.4 branches plant $\left.{ }^{-1}\right)$ had more branches per plant than other varieties at harvest. Nekoma had $43 \%$ more branches per plant compared to Omega, whereas Pembina, Prairie Thunder and York had 67\%, 77\% and 57\% less branches compared to Omega (Figure 1B). 
Omega (24 immature capsules plant ${ }^{-1}$ ) had more immature capsules per plant than other varieties. Nekoma, Pembina, Prairie Thunder and York had 31\%, 67\%, 73\% and 73\% less immature capsules per plant compared to Omega (Figure 1C).

At harvest, Omega (34 capsules plant ${ }^{-1}$ ) and York (31 capsules plant ${ }^{-1}$ ) had more mature capsules per plant compared to the other varieties. Nekoma, Pembina and Prairie Thunder had $54 \%, 51 \%$ and $40 \%$ less mature capsules compared to Omega (Figure 2A). For capsule weight per plant, Omega (1.7 $\mathrm{g} \mathrm{plant}^{-1}$ ) and York $(1.5 \mathrm{~g}$ plant $^{-1}$ ) yielded more compared to other varieties. Nekoma, Pembina and Prairie Thunder yielded 55\%, 49\% and $40 \%$ less compared to Omega (Figure 2B). Similar trends were seen for shoot dry weight. Omega (2.3 g plant $\left.{ }^{-1}\right)$ and York (1.8 $\left.\mathrm{g} \mathrm{plant}^{-1}\right)$ had higher shoot weight compared to other varieties. Compared to Omega, Nekoma, Pembina and Prairie Thunder had 5\%, 49\% and 40\% lower shoot weight (Figure 2B).

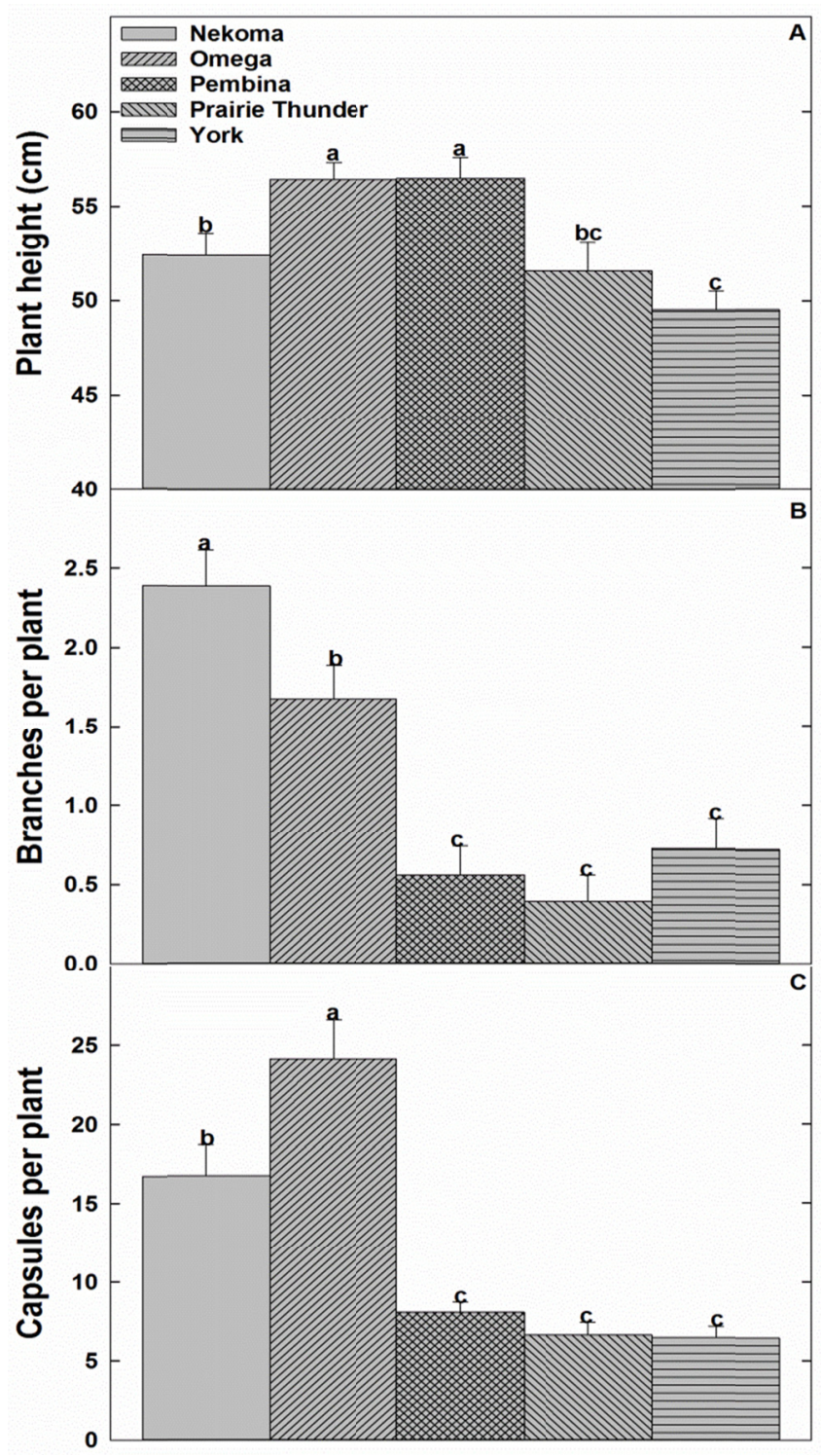

Figure 1. Differences among the flax varieties with respect to plant height, number of branches and immature capsules per plant

Note. Bars with different letters for a particular parameter differed at $\mathrm{P}<0.05$. 


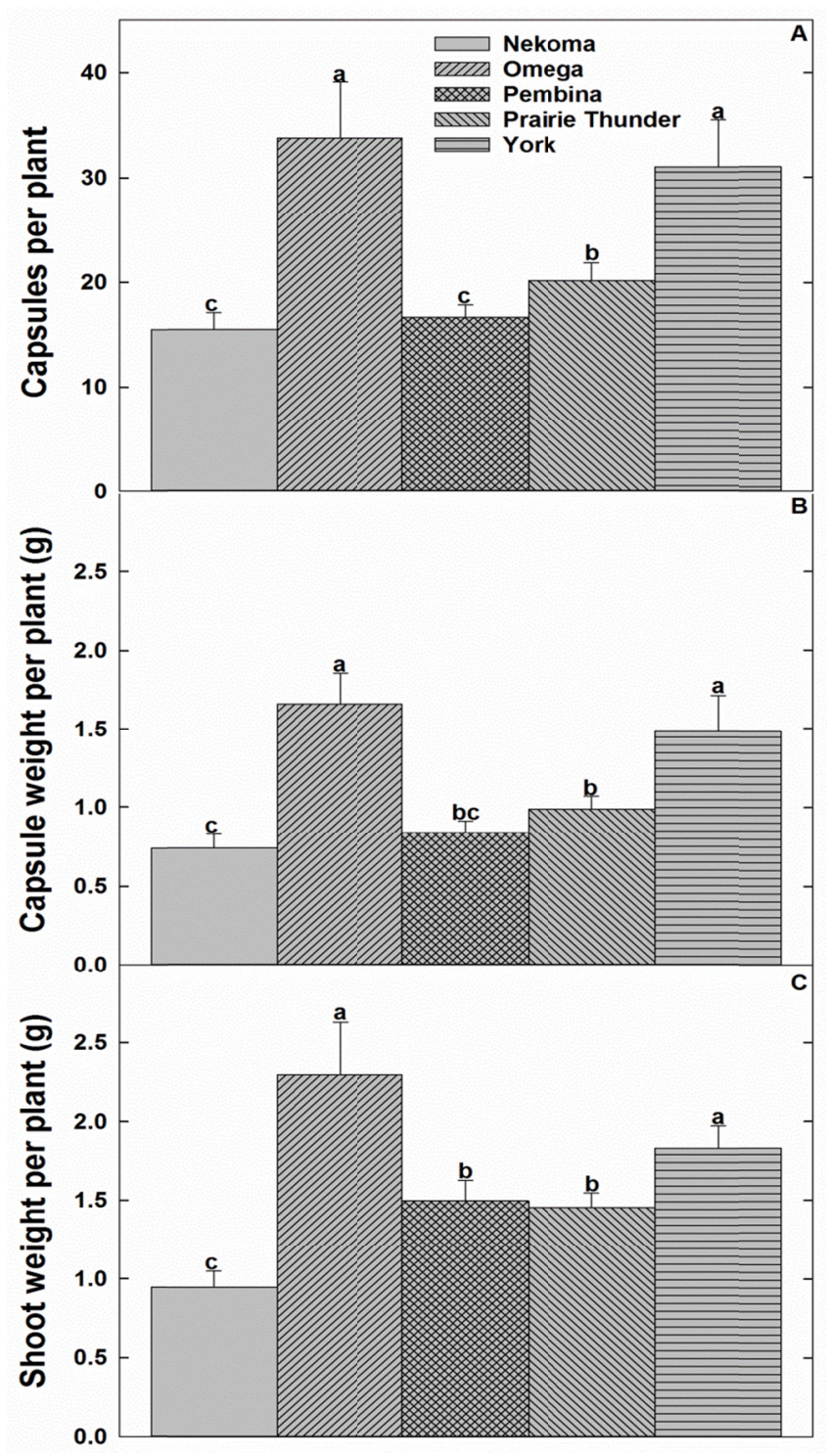

Figure 2. Differences among the flax varieties with respect to mature capsules per plant, capsule weight per plant and shoot weight per plant

Note. Bars with different letters for a particular parameter differed at $\mathrm{P}<0.05$.

\subsection{Mechanical Harvest}

There was no difference between the blocks for yield per hectare. Mechanical harvest was delayed due to bad weather. Capsules shattered as a result of the poor weather (high rainfall). Higher capsule shattering was seen in Omega (data not shown), and Pembina and York yielded 20\% and 38\% more than Omega (625 $\mathrm{kg} \mathrm{ha}^{-1}$; Figure $3)$. 


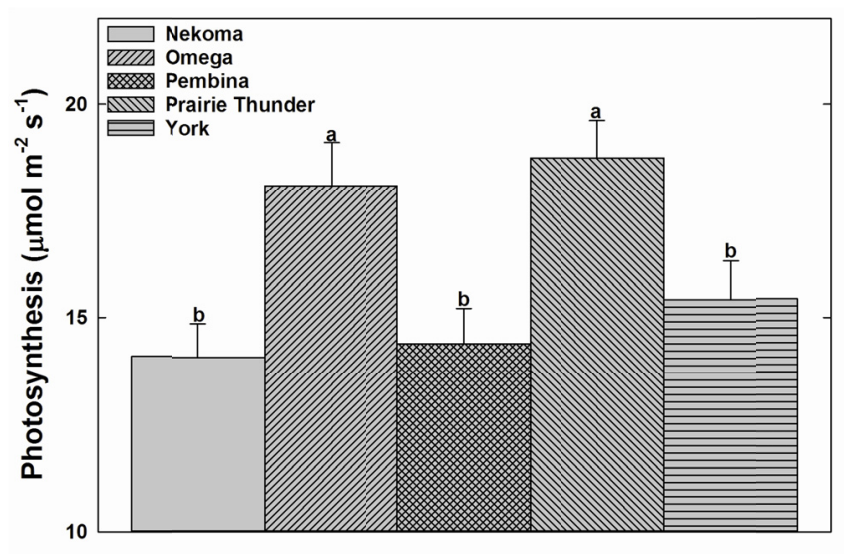

Figure 3. Differences among the flax varieties with respect to photosynthesis

Note. Bars with different letters differed at $\mathrm{P}<0.05$.

\subsection{Leaf Photosynthesis, Seed Oil and Protein Content}

There was no difference between the blocks for leaf photosynthetic rate, oil and protein content. In this study, photosynthetic rate was higher in Omega $\left(18.1 \mu \mathrm{mol} \mathrm{m}^{-2} \mathrm{~s}^{-1}\right)$ and Prairie Thunder $\left(18.8 \mu \mathrm{mol} \mathrm{m}^{-2} \mathrm{~s}^{-1}\right)$, compared to other varieties. Nekoma, Pembina and York showed 22\%, 20\% and 15\% decrease in leaf photosynthetic rate, compared to Omega (Figure 4).

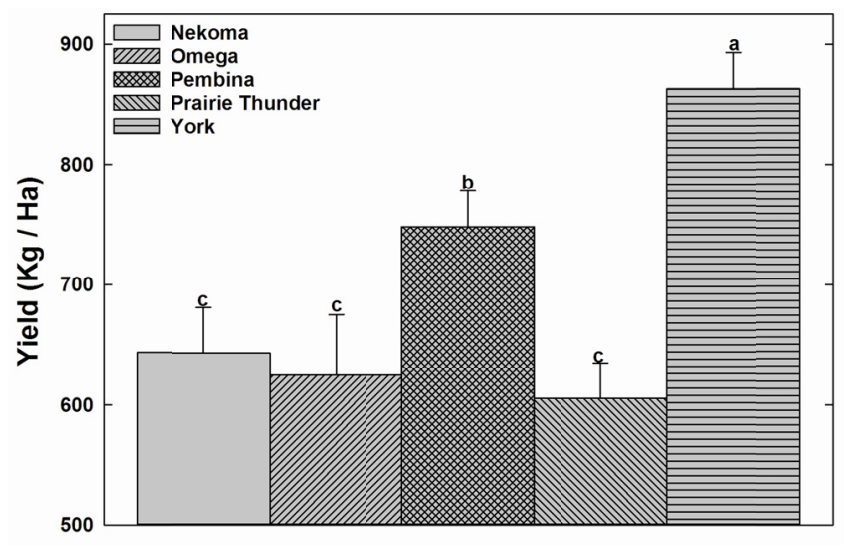

Figure 4. Differences among the flax varieties with respect to yield

Note. Bars with different letters differed at $\mathrm{P}<0.05$.

Nekoma and Pembina had higher oil content compared to other varieties. Nekoma and Pembina had 1\% and 1\% higher oil content and Prairie Thunder and York had 1\% and 4\% less oil content, compared to Omega (Figure $5 \mathrm{~A})$. Omega had a higher protein content compared to other varieties. Nekoma, Prairie Thunder and York had $6 \%, 3 \%$, and $11 \%$ less protein content compared to Omega (Figure $5 \mathrm{~B}$ ). 


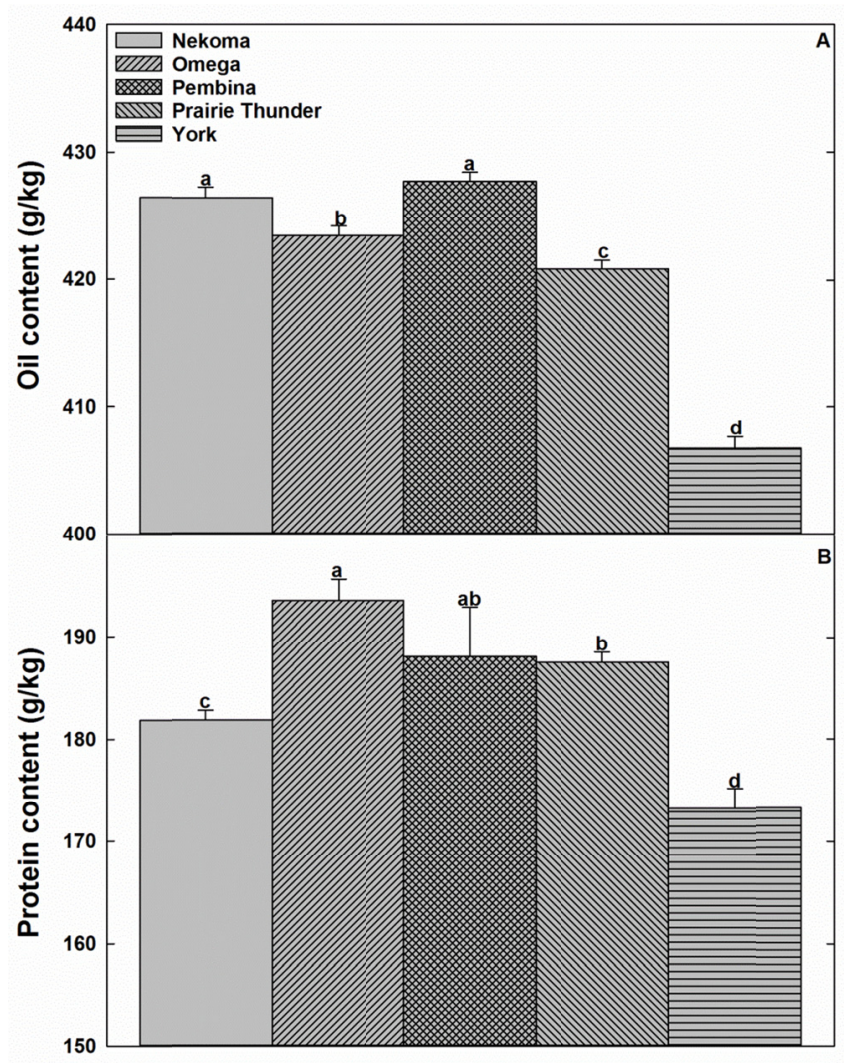

Figure 5. Differences among the flax varieties with respect to oil and protein contents. Bars with different letters for a particular parameter differed at $\mathrm{P}<0.05$

In this study, York had higher oil yield per hectare compared to other varieties. Pembina and York showed 20\% and $33 \%$ more oil yield per hectare, compared to Omega (Figure 6).

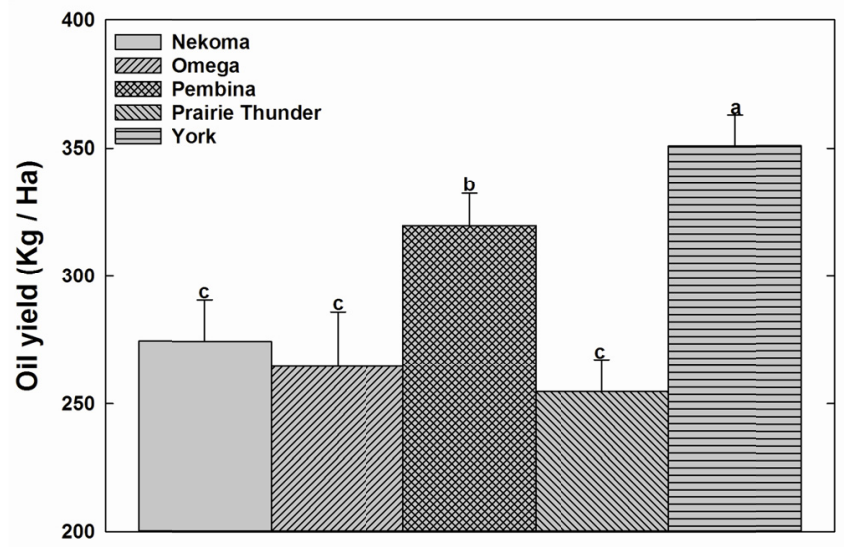

Figure 6. Differences among the flax varieties with respect to oil yield

Note. Bars with different letters differed at $\mathrm{P}<0.05$.

\section{Discussion}

Plant oils are important macromolecules for both human consumption and for industrial applications. Flax seed are sold for human consumption and flax oil (linseed oil) is used in paints and varnishes (Berti, Fischer, Wilckens, Hevia, \& Johnson, 2010). The energy crisis and environmental concerns have increased the interest in 
biodiesel (Dixit et al., 2012). Flax seed oil has potential to be used for biodiesel (Dixit, Kanakraj, \& Rehman 2012). Three main factors which can affect flax seed production are genetic makeup or the varieties, and environmental and agronomic factors (Anastasiu et al., 2016). In the present study, we evaluated the varieties, environmental and agronomic factors affecting flax seed production. Canadian and Northern U.S. flax varieties were grown as a winter crop in the southeast Texas environment on a laser leveled field. In the present study, flax spring varieties from Canada and the Northern U.S. performed well under southeast Texas conditions on a laser-leveled field. Similar results were reported by Darapuneni, Morgan, Ibrahim, and Duncan (2015), where flax varieties performed under south Texas conditions. However, the average flax seed yield in the present study was $700 \mathrm{~kg} \mathrm{ha}^{-1}$, which was much below the average World flax seed yield (943 $\mathrm{kg} \mathrm{ha}^{-1}$; Berti et al., 2010) and recent south Texas (College Station, Texas) average flax yield (1350 $\mathrm{kg} \mathrm{ha}^{-1}$; Darapuneni et al., 2015). However, the flax yield in the present study (Beaumont, Texas) was similar to that of yield at McGregor, Texas (Darapuneni et al., 2015). In the present study, the decrease in the seed yield was due to high rainfall (capsule dehiscence and shattering) and high temperatures during seed development, whereas, the decrease in yield at McGregor Texas was due to cold injury (Darapuneni et al., 2015).

Flax is mainly adapted to temperate climates (Adugna \& Labuschagne, 2003). Temperature plays an important role in determining flax plant stand, plant height, time to reach maturity, seed yield, oil content, and oil composition (Cross et al., 2003; Darapuneni et al., 2015). In the present study, the temperature during the cropping season was between $4{ }^{\circ} \mathrm{C}$ and $30{ }^{\circ} \mathrm{C}$. Hence, no cold injury was noticed in this study. Temperatures below $-2{ }^{\circ} \mathrm{C}$ can cause severe cold injury and can potentially affect plant stand (Darapuneni et al., 2014a). In this study, during the vegetative growth the temperatures were below $20{ }^{\circ} \mathrm{C}$, which is favorable for flax vegetative growth. Temperatures above $20^{\circ} \mathrm{C}$ can hasten senescence of the stem and leaves (Dybing \& Zimmerman, 1965). In the present study, temperatures were higher than $20^{\circ} \mathrm{C}\left(24-30{ }^{\circ} \mathrm{C}\right)$, during seed development. It has been reported that high temperatures during reproductive growth decreases number of mature seed produced per capsule, seed weight and oil content (Dybing \& Zimmerman, 1965). In addition, during the seed development there was high rainfall $(165 \mathrm{~mm})$ causing capsule shattering.

In the present study, flax varieties differed with respect to plant height, number of capsules per plant, photosynthetic rate, yield and oil content. Similar differences among flax varieties were seen with respect to morphological parameters and yield (Berti et al., 2010; Darapuneni et al., 2015). Under optimum conditions flax seeds can yield up from 33-47\% oil content (Dixit et al., 2016). Similar results with respect to flax oil content were reported by Darapuneni et al. (2015). In the present study, the oil content in the varieties varied from $40.7 \%$ to $42.8 \%$. Differences in oil content among flax varieties were reported by Pali and Mehta (2014). There was no correlation observed between the seed yield potential and seed oil content and/or seed protein content. Darapuneni et al. (2015) also showed there was no correlation between seed yield and seed oil content.

\section{Conclusion}

In conclusion, this study indicates that northern spring flax varieties grown as a winter crop in southeast Texas (Beaumont, Texas) environment on a laser-leveled field with $17.8 \mathrm{~cm}$ row spacing performed well with respect to morphology, phenology, physiology, yield and oil content. Due to delayed machine harvest (bad weather-heavy rainfall), there was a decrease in crop yield due to capsule dehiscence and capsule shattering. Genotype Omega had more capsule dehiscence and shattering, compare to other varieties. All the above flax varieties have potential to be used as oilseed crop for biodiesel production in southeast Texas (Beaumont, Texas).

\section{References}

Adugna, W., \& Labuschagne, M. T. (2003). Association of linseed characters and its variability in different environments. The Journal of Agricultural Science, 140, 285-296. https://doi.org/10.1017/S0021859603 003125

Anastasiu, A. E., Chira, N. A., Banu, I., Ionescu, N., Stan, R., \& Rosca, S. I. (2016). Oil productivity of seven Romanian linseed varieties as affected by weather conditions. Industrial Crops and Products, 86, 219-230. https://doi.org/10.1016/j.indcrop.2016.03.051

Berglund, D. R., \& Zollinger, R. K. (2007). Flax production in North Dakota. A-1038 (Revised) publication. North Dakota State University.

Berti, M., Fischer, S., Wilckens, R., Hevia, F., \& Johnson, B. (2010). Adaptation and genotype $\times$ environment interaction of flaxseed (Linum usitatissimum L.) varieties in south central Chile. Chilean Journal of Agricultural Research, 70, 345-356. https://doi.org/10.4067/S0718-58392010000300001 
Can, R. R. A., Yuce, S., \& Demir, I. (2001). Research on some agronomic characteristics of linseed varieties and lines. The 4th Field Crops Congress of Turkey, Proceedings of Plant Breeding (Vol. 1). Tekirado, Turkey: University Of Trakya.

Can, R. R. A., Yuce, S., Aykut, F., \& Furan, M. A. (2003). Relationship among some agronomic characteristics in flax. The 5th Field Crops Congress of Turkey, Proceedings of Plant Breeding (Vol. I). Diyarbakir, Turkey: University of Dicle.

Casa, R., Russell, G., Lo Cascio, B., \& Rossini, F. (1999). Environmental effects on linseed (Linum usitatissimum L.) yield and growth of flax at different stand densities. European Journal of Agronomy, 11, 267-278. https://doi.org/10.1016/S1161-0301(99)00037-4

Cross, R. H., McKay, S. A. B. McHughens, A. G., \& Bonham-Smith, P. C. (2003). Heat stress effects on reproduction and seed-set in Linum usitatissimum L. (flax). Plant Cell and Environment, 26, 1013-1020. https://doi.org/10.1046/j.13653040.2003.01006.x

Darapuneni, M. K., Morgan, G. D., Ibrahim, A. M. H., \& Duncan, R. W. (2014a). Association of flax seed yield and its components in Southeast Texas using path coefficient and biplot analyses. Journal of Crop Improvement, 28, 1-16. https://doi.org/10.1080/15427528.2013.846285

Darapuneni, M. K., Morgan, G. D., Ibrahim, A. M. H., \& Duncan, R. W. (2014b). Effect of vernalization and photoperiod on flax flowering time. Euphytica, 195, 279-285. https://doi.org/10.1007/s10681-013-0996-x

Darapuneni, M. K., Morgan, G. D., Ibrahim, A. M. H., \& Duncan, R. W. (2015). Evaluation of flax varieties for cold tolerance and yield in south-east Texas. Journal of Agronomy and Crop Science, 201, 128-137. https://doi.org/10.1111/jac.12097

Diepenbrock, W., \& Iwersen, D. (1989). Yield development in linseed (Linum usitatissimum L.). Plant Research and Development, 30, 104-125.

Dixit, S., Kanakraj, S., \& Rehman, A. (2012). Linseed oil as a potential resource for bio-diesel: A review. Renewable and Sustainable Energy Reviews, 16, 4415-4421. https://doi.org/10.1016/j.rser.2012.04.042

Dutta, H. K., Ram Mohan Rao, D. S., \& Singh, H. (1995). Response of linseed (Linum usitatissimum L.) to irrigation and nitrogen. Indian Journal of Agronomy, 40, 130-131.

Dybing, C. D., \& Zimmerman, D. C. (1965). Temperature effects on flax (Linum usitatissimum L.) growth, seed production and oil quality in controlled environments. Crop Science, 5, 184-187. https://doi.org/10.2135/ cropsci1965.0011183X000500020029x

Food and Agriculture Organization of the United Nations. (2010). FAOSTAT. Crops (National Production). Retrieved November, 2016, from http://data.fao.org

Hocking, P. J., Randall, P. J., \& Pinkerton, A. (1987). Mineral nutrition of linseed and fiber flax. Advances in Agronomy, 41, 221-296. https://doi.org/10.1016/S0065-2113(08)60806-8

Jhala, A. J., \& Hall, L. M. (2010). Flax (Linum usitatissimum L.): current uses and future applications. Australian Journal of Basic and Applied Science, 4, 4304-4312.

Kaynak, M. A. (1998). Determination of correlation among characters with effects of different amount of seed on yield and yield components of oilseed flax. Harran University Journal of Faculty of Agriculture, 2, 55-64.

National Agricultural Statistics Services-United States Department of Agriculture. (2011). Retrieved November, 2016, from http://quickstats.nass.usda.gov/results/EC38A253-3049-3143-A143-E151BF1562DF

Natural Resources Conservation Services-United States Department of Agriculture. (2006). Retrieved November, 2016, from https://www.nrcs.usda.gov/Internet/FSE_MANUSCRIPTS/texas/TX623/0/Manuscript.pdf

Nie, Z. X. C., Shi, F. T., \& Zhu, C. (1995). Path analysis of characters correlated with seed yield in flax (Linum usitatissimum L.). CAB Abstract, A.N. 951609642.

Pali, V., \& Mehta, N. (2014). Evaluation of oil content and fatty acid compositions of flax (Linum usitatissimum L.) varieties of India. Journal of Agricultural Science, 6, 198-207. https://doi.org/10.5539/jas.v6n9p198

Samonte, S. O. P. B., Wilson, L. T., Medley, J. C., Pinson, S. R. M., McClung, A. M., \& Lales, J. S. (2006). Nitrogen utilization efficiency: Relationships with grain yield, grain protein, and yield-related traits in rice. Agronomy Journal, 98, 168-176. https://doi.org/10.2134/agronj2005.0180

Tiwari, K. P., Dixit, J. P., \& Saran, R. N. (1988). Effect of nitrogen and irrigation on linseed (Linum usitatissimum L.). Indian Journal of Agronomy, 33, 44-46. 
Yang, Y., Wilson, L. T., \& Wang, J. (2010). Development of an Automated Climatic Data Scraping, Filtering and Display System. Computers and Electronics in Agriculture, 71, 77-87. https://doi.org/10.1016/j.compag. 2009.12.006

\section{Copyrights}

Copyright for this article is retained by the author(s), with first publication rights granted to the journal.

This is an open-access article distributed under the terms and conditions of the Creative Commons Attribution license (http://creativecommons.org/licenses/by/4.0/). 